\title{
NEW RECORDS OF LEJEUNEACEAE (MARCHANTIOPHYTA) FOR THE BRAZIL
}

\author{
Cid José PASSOS BASTOS \& Olga YANO
}

\begin{abstract}
RESUMEN. Nuevas citas de Lejeuneaceae (Marchantiophyta) para el Brasil. Se describen e ilustran cuatro nuevas citas de la familia Lejeuneaceae para el Brasil: Drepanolejeunea pinnatiloba Schiffn., Lejeunea elliottii Spruce, Lejeunea filipes Spruce y Lopholejeunea quelchii Steph. Se comenta datos acerca de los habitats, sustratos y distribución geográfica.
\end{abstract}

Palabras clave. Lejeuneaceae, taxonomía, distribución, Brasil, Bahia.

ABSTRACT. New records of Lejeuneaceae (Marchantiophyta) for the Brazil. In this paper Drepanolejeunea pinnatiloba Schiffn., Lejeunea elliottii Spruce, Lejeunea filipes Spruce, and Lopholejeunea quelchii Steph. are described and illustrated. Comments on the habitat, substrates, and geographical distribution are provided.

Key words. Lejeuneaceae, taxonomy, distribution, Brazil, Bahia.

\section{INTRODUCTION}

As a result of recent collecting the knowledge on the Lejeuneaceae from Bahia have been increased considerably. Thus, the range of many species have been widened, and some new records for the Bahia and Brazil have already been published (Bastos \& Vilas Bôas-Bastos, 2000; Bastos \& Yano, 2003), as well as a new species from Brazil was described (Bastos \& Yano, 2002). In this paper four new records for the Brazil are given: Drepanolejeunea pinnatiloba Schiffn., Lejeunea elliottii Spruce, L. filipes Spruce, and Lopholejeunea quelchii Steph.

\section{MATERIALS AND METHODS}

The specimens were collected on excursions carried out in the state of Bahia, Northeastern Brazil, the most of them from ombrophilous forest fragment, domain of Atlantic forest, at southern Bahia. All specimens are deposited at ALCB, SP and HUEFS Herbaria. The species are arranged in alphabetical order.

\section{RESULTS}

Drepanolejeunea pinnatiloba Schiffn., Bot. Jahb. 23: 591. 1827. Fig. 1 
Plants diminutes, $248 \mu \mathrm{m}$ wide, stem 40 $\mu \mathrm{m}$ wide, green, scarcely branched, branches Lejeunea-type. Leaves distant, erectspreading; lobe deep laciniate, 144-204 $\mu \mathrm{m}$ x 48-84 $\mu \mathrm{m}$, segments unisseriate $4-5$ cells long, apical segments lesser, 3-4 cells long; cells oblong to rectangular, 20-24 $\mu \mathrm{m} \times 10$ $12 \mu \mathrm{m}$, thin-walled, trigones and intermediate thickenings absents; oil-bodies not seen; ocelli 2-3 basal, large, 28-32 $\mu \mathrm{m} x$ 18-20 $\mu \mathrm{m}$; lobule ovate, 104-116 $\mu \mathrm{m} \times$ x $72-$ $76 \mu \mathrm{m}$, inflated, free margin involute, apical tooth acute, falcate, apical margin straight, keel arched, crenate; hyaline papilla proximal at apical tooth base. Underleaves small, 30-42 $\mu \mathrm{m}$ wide, distant, lobes unisseriate, 3 cells long, 2 cells wide at base, divergent to parallel, sinus lunate to widely acute, base partially sheldon by rhizoids. Ventral merophytes two cells wide. Androecium and gynoecium not found.

Selected material: Brazil, Bahia: Estação Veracruz Ecological Reserve, between towns of Eunápolis and Porto Seguro, 16²2'00"S, 3908'28”W, 10/9/ 1999, C. Bastos \& S.B. Vilas Bôas-Bastos 1858pp. (ALCB).

Distribution and habitat: neotropical, reported for Cuba and Porto Rico (Bischler, 1964). The specimens were collected in ombrophilous lowland forest growing on the tree trunk, mixed to Cheilolejeunea rigidula (Mont.) Schust.

Lejeunea elliottii Spruce, J. Linn. Soc. Bot. 30: 346. 1895. Figs. 2, 3.

Plants small, $720 \mu \mathrm{m}$ wide, pallid-green, branches Lejeunea-type. Stems in cross section with 7 cortical cells and 4 medullary cells. Leaves contiguous to imbricate, spreading; lobe ovate, 368-400 $\mu \mathrm{m}$ x 232$296 \mu \mathrm{m}$, antical margin arched, strongly crenate by projecting cells, postical margin weakly arched to straight, crenate, apex rounded to obtuse; cells oblong-hexagonal, 26-46 $\mu \mathrm{m} \times 18-24 \mu \mathrm{m}$, thin-walled, trigones small to inconspicuous, intermediate thickenings inconspicuous; oil-bodies not seen; lobule ovate, $120-140 \mu \mathrm{m}$ x 92-100 $\mu \mathrm{m}$, inflated, free margin plane, involute at proximal portion, apical tooth oblong, apical margin oblique to lunate, keel arched; hyaline papilla proximal at the apical tooth base. Underleaves small, 60-132 $\mu \mathrm{m}$, distant, oblong to trapezoidal, sinus widely acute to lunate, base cuneate, insertion line arched. Ventral merophytes two cells wide. Autoicous. Androecium on short branch, 23 pairs of bracts, bracteole at the base of branch. Gynoecium on short branch, sterile lejeuneoid innovation, bracts short, lobe obovate, margin crenate, lobule oblong, apex rounded, bracteole oblong, bifid, sinus acute, margin entire to crenate; perianth obovate, 5-keeled, keels winged, strongly crenate by long projecting cells, rostrum distinct. Asexual reproduction likely by margin fragmentation of the leaf lobe.

Selected specimens: Brazil, Bahia: Estação Veracruz Ecological Reserve, between Eunápolis and Porto Seguro, $16^{\circ} 22^{\prime} 47^{\prime} \mathrm{S}, 39^{\circ} 10^{\prime} 20^{\prime} \mathrm{W}, 8 / 9 / 1999$, C. Bastos \& S.B. Vilas Bôas-Bastos 1628 (ALCB).

Distribution and habitat: Neotropical, reported for Cuba, Dominica, St. Vicent and Guyana (Reiner-Drehwald \& Goda 2000). The specimens were collected in ombrophilous lowland forest, domain of Atlantic Forest, growing on tree trunk.

Lejeunea filipes Spruce, Trans. Proc. Bot. Soc. Edinburgh 15: 275. Fig. 4

Plants small, $0.5 \mathrm{~mm}$ wide, green, branches Lejeunea-type. Stem in cross section with 7 cortical cells and 4-6 medullary cells. Leaves spreading to suberet, contiguous; lobe ovate, 164-244 $\mu \mathrm{m}$ x 136- 

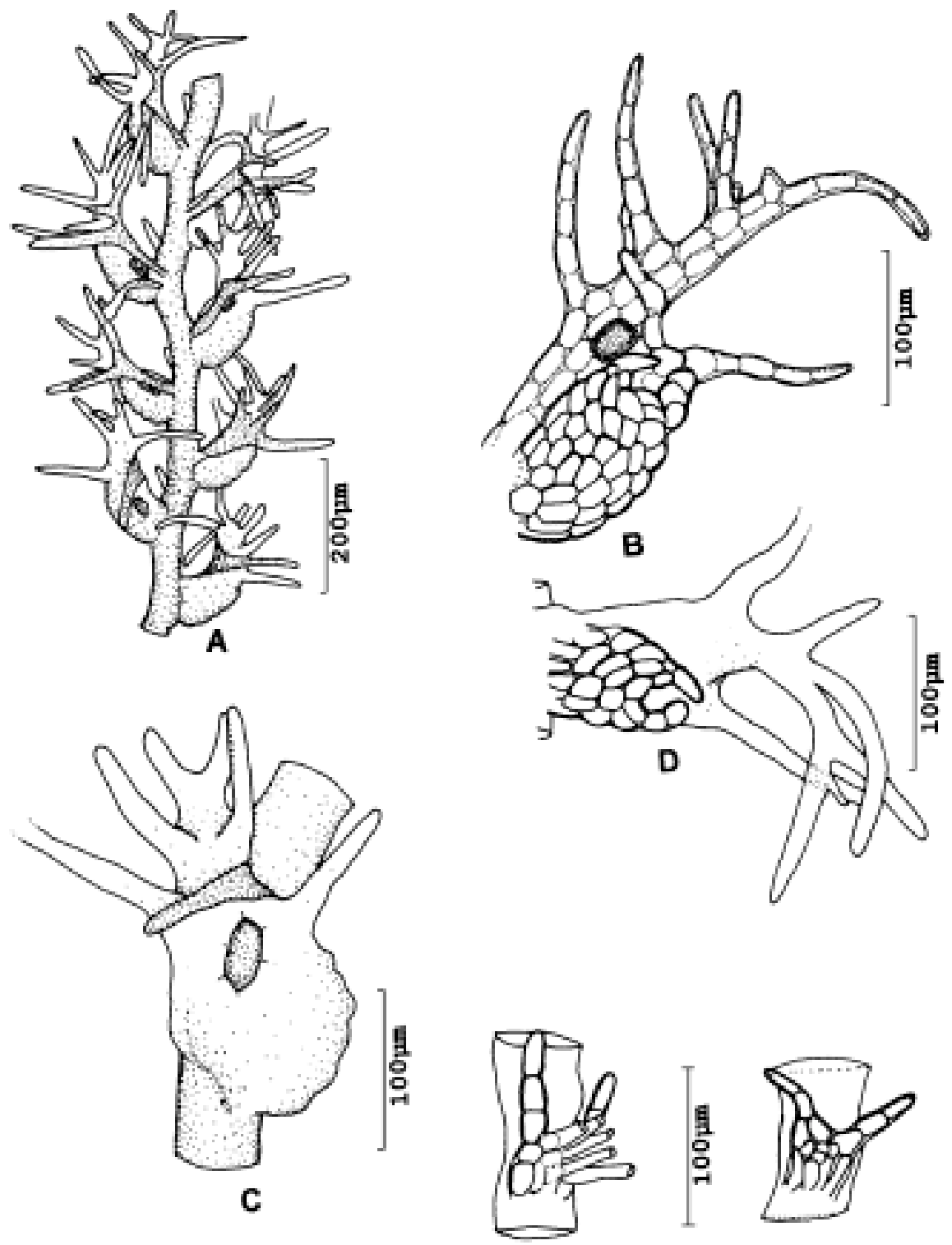

$\mathbf{E}$

Figure 1. Drepanolejeunea pinnatiloba Schiffn. A: plant, ventral view; B: leaf, ventral view; C: leaf, dorsal view; D: lobule; E: underleaves (C. Bastos \& S.B. Vilas Bôas-Bastos 1858pp.). 

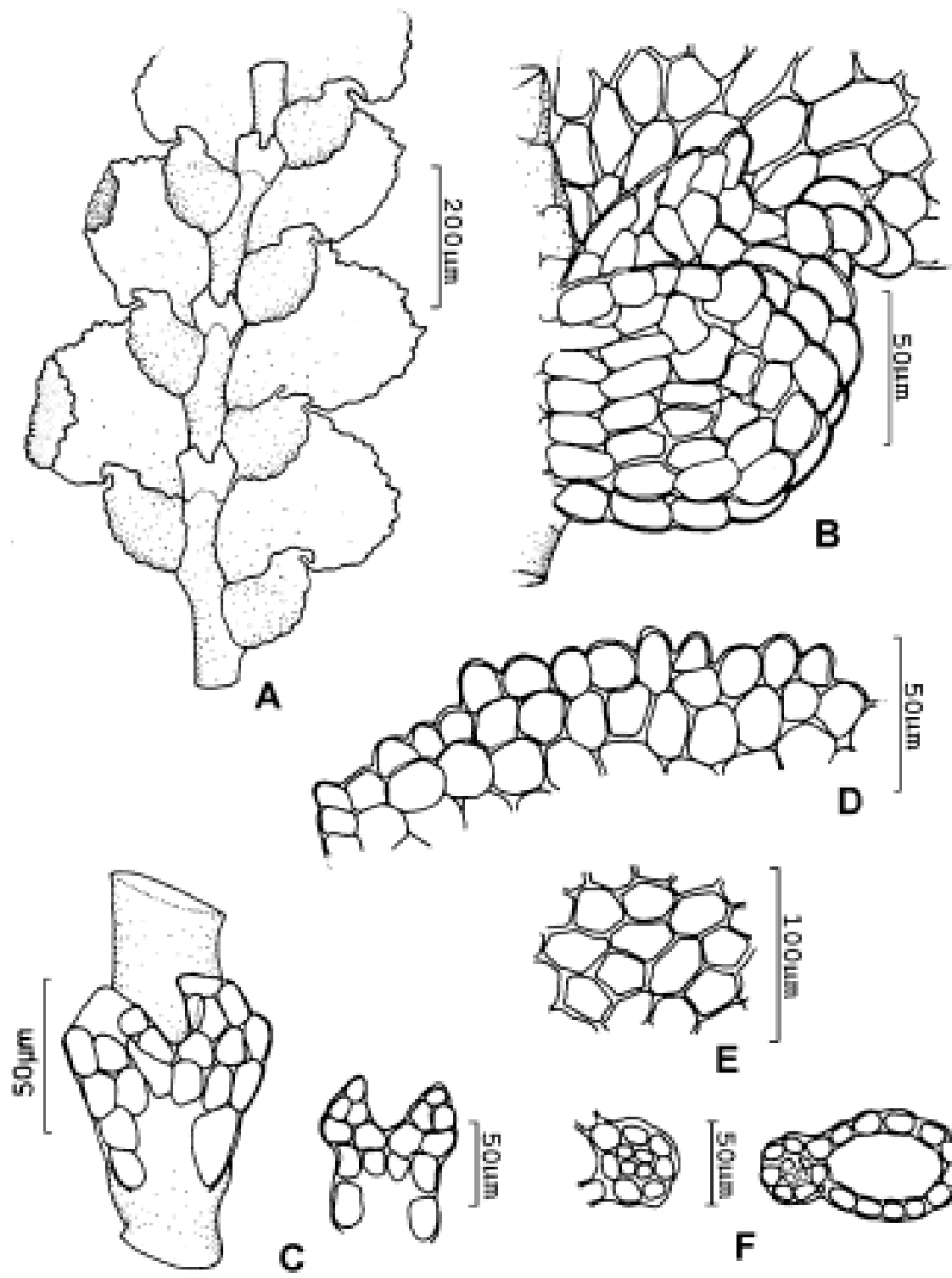

\section{E}
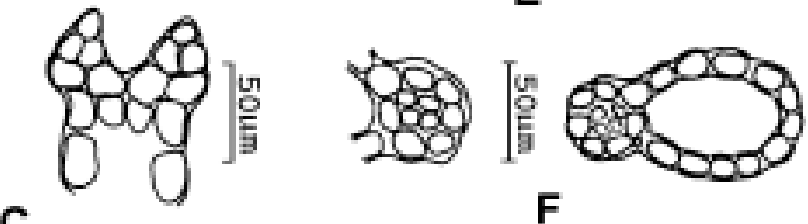

F

Figure 2. Lejeunea elliottii Spruce. A: gametophyte, ventral view; B: lobule and basal cells of the lobe; C: underleaves; D: marginal cells of the leaf lobe; E: laminal cells; F: cross-sections of the stem (C. Bastos 1628). 

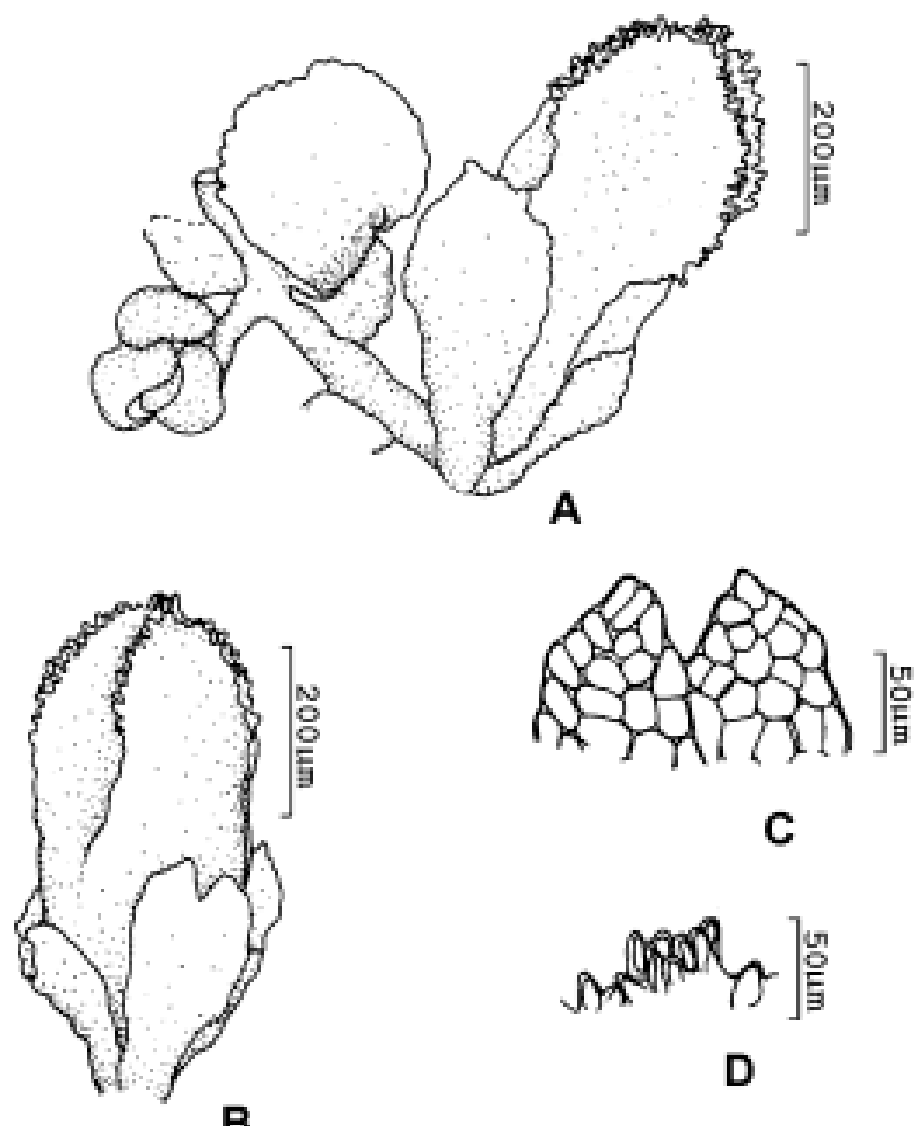

B

Figure 3. Lejeunea elliottii Spruce. A: gynoecium and androecial branch, ventral view; B: gynoecium with perianth; C: Bracteole apex; D: detail of perianth apex (C. Bastos 1628:

$220 \mu \mathrm{m}$, antical margin arched, entire to crenate, postical margin arched, entire, apex acute or rounded; cells oblong to hexagonal, 14-24 $\mu \mathrm{m} \times 10-12 \mu \mathrm{m}$, thin-walled, cuticule verrucose, trigones small to inconspicuous, intermediate thickenings absent; oil-bodies not seen; ocelli absent; lobule ovate, 100$124 \mu \mathrm{m} \times$ 84-108 $\mu \mathrm{m}$, inflated, free margin involute, apical tooth oblong, apical margin curved, keel arched; hyaline papilla proximal at apical tooth base; reduced lobules occasionall. Underleaves small, 56-60 $\mu \mathrm{m}$ wide, distant, lobes weakly distinct, sinus acute to lunate, base cuneate, insertion line straight to transverse. Ventral merophytes two cells wide. Autoicous. Androecium intercalar, terminal or on short lateral branch, 2-5 pair of bracts, bracteole at the base of spike. Gynoecium terminal, pycnolejeuneoid innovation, bracts with lobe ovate, margin entire, apex acute, lobule oblong, apex acute; bracteole oblong, bifid, sinus acute; perianth 
obovate, 5-keeled, keels smoth to crenate, rostrum short.

Selected specimens: Brazil, Bahia: Estação Veracruz Ecological Reserve, between Eunápolis and Porto Seguro, 9/6/ 1999, 16²2'S, 39¹0'W, S.B. Vilas BôasBastos \& C. Bastos 401 (ALCB); Santa Terezinha, Serra da Jibóia, $12^{\circ} 52^{\prime} \mathrm{S}$, $39^{\circ} 28^{\prime} \mathrm{W}, 4 / 3 / 2001$, E.B. Valente et al. 57 (HUEFS).

Distribution and habitat: neotropical, reported for Dominica, Peru, and Argentina (Reiner-Drehwald, 2000). The specimens were collected in ombrophilous and seasonal forest, growing on the tree trunk.

Lopholejeunea quelchii Steph., Malpighia 10: 520. 1896. Fig. 5

Plants robust, 1.3-1.4 mm wide, brown, branches Lejeunea-type. Stem in cross section with 15 cortical cells, 35 medullary cells. Leaves spreading, imbricate; lobe ovate, 0.7-0.9 $\mu \mathrm{m} \times 0.5-0.6 \mu \mathrm{m}$, antical margin arched, entire, postical margin straigth to weakly arched, entire, apex rounded; cells oblong to rounded, 23.7-34.3 $\mu \mathrm{m} \times 22.4-27.7 \mu \mathrm{m}$, thick-walled, trigones large, intermediate thickenings nodulose; oilbodies not seen; ocelli absent; lobule ovate, 238.0-291.5 $\mu \mathrm{m}$ x 185.5 × $227.9 \mu \mathrm{m}$, free margin involute, plane toward apex, apical tooth short to inconspicuous, apical margin oblique, keel arched; hyaline papilla marginal. Underleaves orbicular to reniform, entire, 0.5-0.6 $\mu \mathrm{m}$ wide, margin entire, base cuneate, insertion line arched. Ventral merophytes four cells wide. Androecium lateral, 7-14 pairs of bracts, lobules inflated, bracteoles present throughout. Gynoecium terminal, pseudo-innovations of Lejeuneatype, bracts with lobe obovate, margin dentate, apex apiculate, incurved, lobule narrow ligulate to oblong; bracteole ovate, short bifid, margin dentate; perianth exserted, obovate, lateral and ventral keels dentate above, rostrum short.

Selected specimens: Brazil, Bahia: Estação Veracruz Ecological Reserve, between towns of Eunápolis and Porto Seguro, 16²2'47"S, 39¹0'20”W, 8/9/1999, C. Bastos \& S.B. Vilas Bôas-Bastos 1536 (ALCB).

Distribution and habitat: neotropical, reported for Cuba, Puerto Rico, Saba, Guadeloupe, Guyana and Suriname (Gradstein, 1994). The specimens were found in primary lowland ombrophilous forest, domain of Atlantic forest, growing on tree trunk.

\section{DISCUSSION}

Lejeunea Libert is a large and complex genus of Lejeuneaceae, whose circumscription is somewhat controversial, at least for some species. In Brazil the genus need to be revised, since it has not been studied in this country. Thus, the real situation of the genus in Brazil is not known. Lejeunea filipes in despite of has not been reported for Brazil, there are references for Lejeunea autoica Schust. from São Paulo by Visnadi (1998), a likely synonymy for these species according to Reiner-Drehwald (2000). In fact $L$. filipes is very similar to $L$. autoica described and illustrated by Schuster (1980), and to African L. confusa illustrated and described by Jones (1972). However, $L$. confusa is dioicous, but may be conspecific to L. filipes.

Drepanolejeunea is a large tropical and subtropical genus, with ca. 150 species, occurring in Asia, Africa, and America. In Brazil it is represented by 20 species, five of these occur in the state of Bahia. D. pinnatiloba was reported for Costa Rica and Cuba, and their presence in the Bahia may be an indication of a wider distribution in 

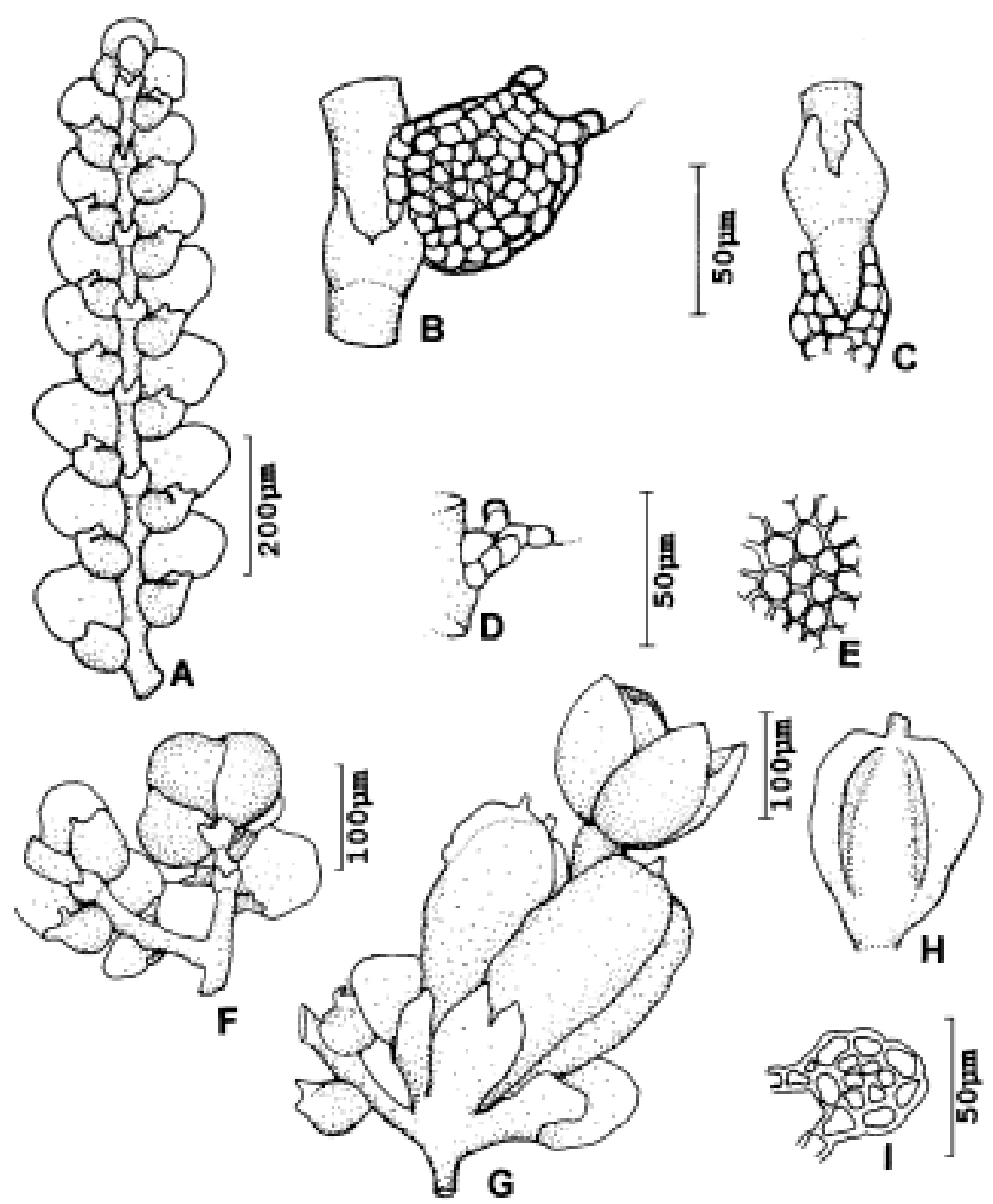

Figure 4. Lejeunea filipes Spruce. A: gametophyte, ventral view; B: underleaf and lobule; C: underleaves; D: reduced lobule; E: laminal cells; F: androecium; G: gynoecium; H: perianth; I: crosssection of the stem (E. Melo et al. 2673). 


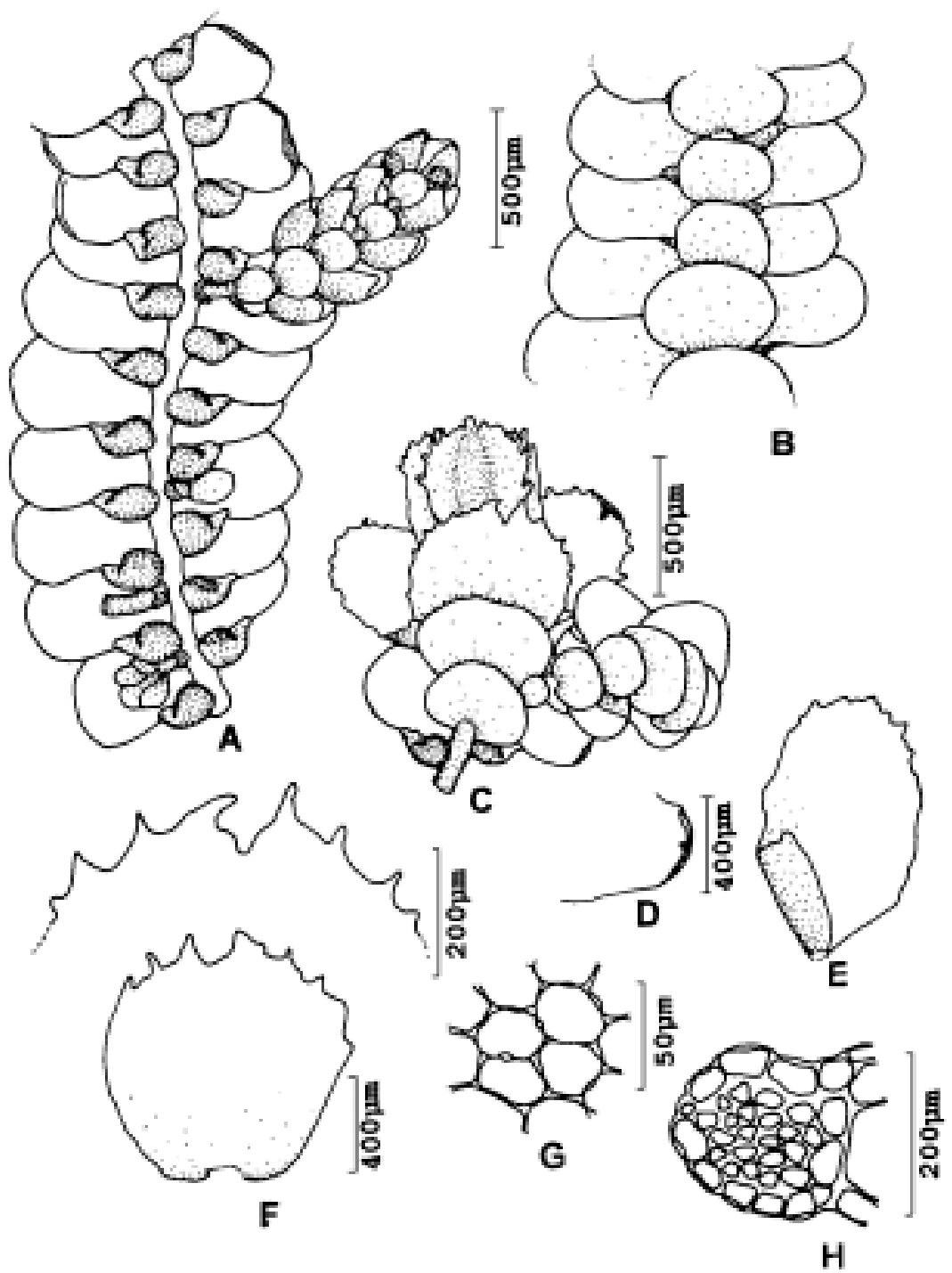

Figure 5. Lopholejeunea quelchii Steph. A: gametophyte, ventral view; B: gametophyte with underleaves; C: gynoecial branch, ventral view; D: bract apice; E: bract; F: braceteole and apice; G: laminal cells; H: cross-section of the stem (C. Bastos \& Vilas Bôas-Bastos 1638). 
Brazil.

Lopholejeunea is a pantropical genus, with more than 45 species recognized, mostly occurring in paleotropics. Four species occur in Tropical America, three of which have a pantropical distribution ( $L$. nigricans, L. subfusca, and L. eulopha). Lopholejeunea quelchii according to Gradstein (1994) its rare Caribbean species and may be considered a threatened species because its rarity and its growth in undisturbed rain forest.

The presence of these Neotropical elements in the state of Bahia may be indicative of needed the more inventory and taxonomic study of the Brazilian bryophyte flora, in order to amplify of range of these elements. Thus, the increment of the collecting effort in the other areas of the country will provide a more source of data on the Brazilian bryophyte flora.

\section{REFERENCES}

BASTOS, C.J.P. \& S.B. VILAS BÔAS-BASTOS -2000- Occurrence of some Lejeuneaceae (Jungermanniophyta) in Bahia, Brazil. Trop. Bryol. 19: 45-54.

BASTOS, C.J.P. \& O. YANO - 2002Pycnolejeunea porrectilobula (Lejeuneaceae), a new species from Brazil. Nova Hedwigia 74: 439-443.

BASTOS, C.J.P. \& O. YANO -2003- New records of the genus Rectolejeunea (Lejeuneaceae) for the state of Bahia, Brazil. Nova Hedwigia 76: 477-485.

BISCHLER, H. -1964- Le genre Drepanolejeunea Steph. in Amérique Centrale et Méridionale.'Revue Bryol. Lichénol. 33: 95-134.
GRADSTEIN, S.R. -1994- Lejeuneaceae: Ptychantheae, Brachiolejeuneae. Flora Neotropica, Monograph 62: 1-216.

JONES, E.W. -1972- African hepatics XXIII. Some species of Lejeunea. J. Bryol. 7: 2345.

REINER-DREHWALD, M.E. -2000- Las Lejeuneaceae (Hepaticae) de Misiones, Argentina VI. Lejeunea y Taxilejeunea. Trop. Bryol. 19: 81-131.

REINER-DREHWALD, M.E. \& A. GODA 2000- Revision of the genus Crossotolejeunea (Lejeuneaceae, Hepaticae). J. Hattori Bot. Lab. 89: 1-54.

SCHUSTER, R.M. -1980- Hepaticae and Anthocerotae of North America east Handredht Meridian. Vol. IV. New York: Columbia University Press.

VISNADI, S.R. -1998- Briófitas em Ecossistemas Costeiros do Núcleo Picinguaba do Parque Estadual da Serra do Mar, Ubatuba-SP. Tesis Doctoral. Universidade Estadual Paulista. 274 p.

Aceptado para su publicación en septiembre de 2004

Authors's Address. C.J. Pasos Bastos: Universidade Federal da Bahia. Instituto de Biologia. Departamento de Botânica. Laboratório de Taxonomia de Algas e Briófitas. Campus de Ondina. 40170-280 Salvador - Bahia - Brazil. O. Yano: Instituto de Botânica, Seção de Briologia e Pteridologia, Caixa Postal 4005, 01061-970 São Paulo, SP, Brasil. 